Article

\title{
Scale-Up of Self-Regenerating Semi-Batch Adsorption Cycles through Concurrent Adsorption and Reduction of Cr(VI) on Sheep Wool
}

\author{
Mohamed Badrelzaman ${ }^{1}{ }^{\circledR}$, Mustafa I. Khamis ${ }^{2}$, Taleb H. Ibrahim ${ }^{1, *}$ and Fawwaz H. Jumean ${ }^{2}$ \\ 1 Department of Chemical Engineering, American University of Sharjah, Sharjah 26666, UAE; \\ mbadrelzamanm@aus.edu \\ 2 Department of Biology, Chemistry and Environmental Sciences, American University of Sharjah, \\ Sharjah 26666, UAE; mkhamis@aus.edu (M.I.K.); fjumean@aus.edu (F.H.J.) \\ * Correspondence: italeb@aus.edu
}

Received: 6 August 2020; Accepted: 30 August 2020; Published: 2 September 2020

\begin{abstract}
A previous publication by our group reported that adsorption of $\mathrm{Cr}(\mathrm{VI})$ on sheep wool reached $99 \%$ when allowed a long residence time, with concurrent reduction to $\mathrm{Cr}(\mathrm{III})$. In this study, the process was scaled up by optimizing a pilot plant based on semi-batch adsorption cycles. This yielded $\mathrm{Cr}(\mathrm{III})$, which is about 300 times less toxic than $\mathrm{Cr}(\mathrm{VI})$, and can be precipitated using lime at high $\mathrm{pH}$. Since the reduction step is slower than the adsorption one, an adsorption column was designed to perform semi-batch operation cycles, whereby the extended "off cycle" allows reduction to take place. Since reduction of $\mathrm{Cr}(\mathrm{VI})$ frees active sites on wool, the plant acts in lieu of in situ regeneration, accompanied by additional adsorption of $\mathrm{Cr}(\mathrm{VI})$. The results show that $97 \%$ of the column efficiency can be recovered within $24 \mathrm{~h}$ of "off cycle". Wastewater from a local electroplating industry was treated by this method with high removal of $\mathrm{Cr}(\mathrm{VI})$, reaching the limit permitted by environmental standards. This study also reveals that typical concentrations of heavy metals, present in wastewater produced from electroplating, had no substantial antagonistic interference with $\mathrm{Cr}(\mathrm{VI})$ adsorption.
\end{abstract}

Keywords: hexavalent chromium; wool; adsorption; semi-batch adsorption cycles; industrial wastewater

\section{Introduction}

Trace concentrations of chromium are essential for metabolism in the human body, with a recommended 50-200 $\mu \mathrm{g}$ daily diary intake for $\mathrm{Cr}$ (III) [1]. At higher concentrations, however, chromium has high toxicity and epidemiological studies show evidence of carcinogenic potential in the case of inhaled $\mathrm{Cr}(\mathrm{VI})$. Other adverse health impacts to chronic and acute exposure include ulcerations, bronchitis, and decreased pulmonary function, as well as damage to liver, kidney, and immune systems [2].

Chromium and chromium containing chemicals are used in a host of chemical industries [3]. Chromium compounds are present in natural and synthetic pigments [4]. The name chromium is from the Greek "chroma", meaning color [5]. Cr(VI) is used as a corrosion inhibitor for aluminum alloys [6]. Such industrial applications raise concerns about environmental contamination from waste effluents containing toxic chromium compounds.

Unlike the case with other heavy metals, chromium toxicity depends on valence, the most stable states being $\mathrm{Cr}(\mathrm{III})$ and $\mathrm{Cr}(\mathrm{VI})$ [7], with the latter being more toxic [1]. The most toxic route of exposure to $\mathrm{Cr}(\mathrm{VI})$ is inhalation. $\mathrm{Cr}(\mathrm{VI})$ in compounds such as chromate $\left(\mathrm{CrO}_{4}^{-2}\right)$, dichromate 
$\left(\mathrm{Cr}_{2} \mathrm{O}_{7}^{-2}\right)$, and chromium trioxide $\left(\mathrm{CrO}_{3}\right)$ are known carcinogens when inhaled [8]. They are strictly regulated by occupational safety authorities worldwide. The toxicity of $\mathrm{Cr}(\mathrm{VI})$ is attributed to its water solubility and permeability through cell membranes [9]. Absorption of water-soluble chromates in the blood is high, whereas insoluble chromates have lower absorption and longer residence time in lungs. The established exposure limit for inhaled $\mathrm{Cr}(\mathrm{VI})$ is $5 \mathrm{mg} / \mathrm{m}^{3}$ for an 8 -h time-weighted average [10]. Chromium is also toxic to marine organisms, but, in contrast with the case in humans, $\mathrm{Cr}$ (III) is more toxic for these organisms than $\mathrm{Cr}(\mathrm{VI})$ [11]. Both $\mathrm{Cr}(\mathrm{III})$ and $\mathrm{Cr}(\mathrm{VI})$ are toxic to microorganisms used in wastewater treatment [12].

$\mathrm{Cr}(\mathrm{VI})$ can be treated by reduction to the less toxic $\mathrm{Cr}(\mathrm{III})$, or by removal using ion exchange [13], nanofiltration [14], reverse osmosis [15], and phyto-remediation [16]. After reduction, $\mathrm{Cr}(\mathrm{III})$ can be precipitated by raising the $\mathrm{pH}$ in order to favor precipitation of chromium compounds containing $\mathrm{S}^{-2}$ or $\mathrm{OH}^{-}$[17]. Biosorption, in which biomass is used to adsorb chromium, has also been used, with reported removal efficiencies in excess of $90 \%$ [18]. However, the fate of the highly toxic $\mathrm{Cr}(\mathrm{VI})$ remains a serious concern after its adsorption.

Keratin based natural adsorbents, found in animal horns and wool, have the capacity to adsorb heavy metals such as mercury, copper, cadmium, zinc, arsenic, lead, and chromium [19]. For chromium, previous studies show very high removal efficiencies on wool when compared to other natural adsorbents such as olive cake, sawdust, pine needles, almond shells, cactus leaves, and coal [20]. Removal efficiencies ranging between 80 and $99 \%$ for $\mathrm{Cr}(\mathrm{VI})$ on wool have been demonstrated in a batch sequential reactor study, with the wool exhibiting no decline in removal efficiency even when regenerated with $\mathrm{KCl}$ in repeated cycles [21]. Another study reported up to $99 \%$ removal after a long residence time on sheep wool. Furthermore, $\mathrm{Cr}(\mathrm{VI})$ is not only adsorbed on wool but is also reduced to $\mathrm{Cr}(\mathrm{III})$ [22]. For short-term studies, external mass transfer controls adsorption, whereas intra-particle diffusion controls diffusion at later stages [23].

Reduction is a key feature of sheep wool when used as adsorbent for $\mathrm{Cr}(\mathrm{VI})$. Other adsorbents may have high adsorption capacity that could reach values as high as five times that with sheep wool [24]. However, in absence of accompanying reduction, the process will require regeneration and further treatment of effluent. A material that is reported to exhibit similar reduction behavior to sheep wool is activated carbon, with which $30 \%$ of $\mathrm{Cr}(\mathrm{VI})$ in the feed can be reduced to $\mathrm{Cr}$ (III) [25]. However, that observation has not been utilized to decrease the need for regeneration.

This study aimed at optimizing residence time in a semi-continuous adsorption column in which reduction occurs at values sufficient to permit operation without regeneration. With optimum adsorption/reduction cycles, an auto-regenerated column is shown to be effective. The product from such a column is $\mathrm{Cr}(\mathrm{III})$, which is about 300 times less toxic than $\mathrm{Cr}(\mathrm{VI})$ and can be precipitated using lime at high $\mathrm{pH}$ [26], or adsorbed efficiently by modified adsorbents [27].

\section{Materials and Instrumentation}

\subsection{Materials}

All chemicals were of analytical grade and were used without further purification. Solutions were prepared using distilled deionized water (DDW) and their concentrations determined spectrophotometrically. Potassium dichromate, used as a source of $\mathrm{Cr}(\mathrm{VI})$, was from Riedel De-Haen (Seelze, Germany). Acetone and 5-di-phenyl carbazide were from Sigma Aldrich (St. Louis, MO, USA). Sheep wool (Sharjah animal market) was trimmed, riffled, and then washed with water and detergent for two days.

\subsection{Instrumentation}

$\mathrm{Cr}(\mathrm{VI})$ concentrations were determined on an Evolution 220 spectrophotometer (ThermoFischer Scientific, Waltham, MA, USA) at $540 \mathrm{~nm}$, using the 1,5 diphenyl carbazide method. Total Cr was measured using inductively coupled plasma (ICP) (VARIAN, LIBERTY AX Sequential-ICP-OES, 
coupled with SPS3 sample preparation system, and LYTRON cooling system). The difference between total $\mathrm{Cr}$ and $\mathrm{Cr}(\mathrm{VI})$ was taken to be $\mathrm{Cr}(\mathrm{III})$. ICP was also used to measure concentrations of $\mathrm{Cu}, \mathrm{Mn}, \mathrm{Ni}$, $\mathrm{Pb}$, and $\mathrm{Zn}$ in electroplating wastewaters. Columns were manufactured in our lab. Masterflex L/S dosing pump with four channels was used to supply feeds at the desired flow rate.

\section{Methods}

\subsection{Sample Preparation}

Wool was soaked in water for one day to loosen debris and then washed with detergent to remove lipids. This was followed by air drying at $40{ }^{\circ} \mathrm{C}$ for $6 \mathrm{~h}$. Wool was cut in ca. $2 \mathrm{~cm}$ long strips for packing columns. Stock $\mathrm{Cr}(\mathrm{VI})$ solutions were prepared from potassium dichromate and used in feed solutions for preliminary column studies. The $\mathrm{pH}$ of the feed solution was adjusted to $2.0 \mathrm{using} \mathrm{HCl}$. Wastewater from a local electroplating company was diluted and adjusted to this $\mathrm{pH}$. After dilution, the solution had the composition shown in Table 1 . This solution was used to assess the performance of the semi-continuous column in presence of other heavy metals.

Table 1. Electroplating waste composition (after dilution and $\mathrm{pH}$ adjustment).

\begin{tabular}{cc}
\hline Heavy Metal & Concentration, $\mathbf{m g} / \mathbf{L}$ \\
\hline $\mathrm{Cr}($ Total $)$ & $8.6 \times 10^{2}$ \\
$\mathrm{Cr}(\mathrm{VI})$ & $6.2 \times 10^{2}$ \\
$\mathrm{Cr}(\mathrm{III})$ & $2.3 \times 10^{2}$ \\
$\mathrm{Cu}$ & 14 \\
$\mathrm{Mn}$ & 0.30 \\
$\mathrm{Ni}$ & 32 \\
$\mathrm{~Pb}$ & 0.90 \\
$\mathrm{Zn}$ & 3.2 \\
\hline
\end{tabular}

\subsection{Continuous Flow Experiments}

A fixed bed column packed with sheep wool was prepared with inner and outer diameters of 32 and $40 \mathrm{~mm}$. It had a packing height of $106 \mathrm{~mm}$ and a packing density of $100 \mathrm{~g} / \mathrm{L}$. The layout of the process is shown in Figure 1. The column was washed with $\mathrm{HCl}$ and the $\mathrm{pH}$ brought down to 2.0. Prepared feed was then passed through the column. Samples were collected at time intervals and analyzed for $\mathrm{Cr}(\mathrm{III})$ and $\mathrm{Cr}(\mathrm{VI})$. Wastewater was fed to the column for 5 min at a flow rate of $200 \mathrm{~mL} / \mathrm{min}$. The column was then left undisturbed for $55 \mathrm{~min}$ and the cycle repeated several times. The column was finally left for $24 \mathrm{~h}$, labeled as a dark interval. Following this interval, the column was operated again using the same cycles. 


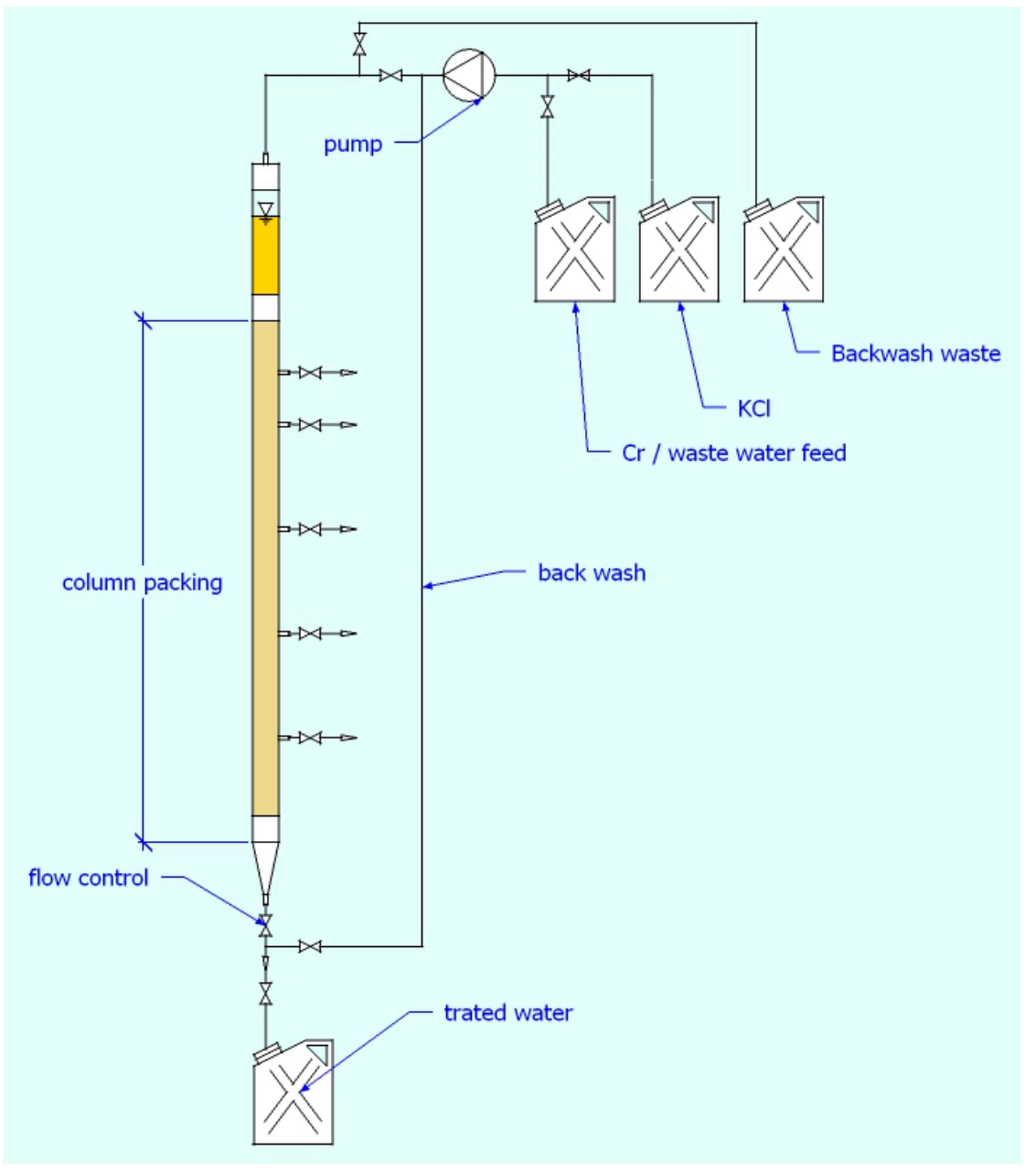

Figure 1. Packed column experimental setup.

\section{Results and Discussion}

The following conditions from our previous work on batch sequential reactors [21] were used: Wool dosage $=8.0 \mathrm{~g} / \mathrm{L}$, contact time $=25 \mathrm{~min}, \mathrm{pH}=2.0, \mathrm{~T}=25.0^{\circ} \mathrm{C}$, initial $\mathrm{Cr}(\mathrm{VI})$ concentration $=100 \mathrm{mg} / \mathrm{L}$, and regeneration using 1.0-m KCl. For the first semi-continuous column trial shown in Figure 2, $100 \mathrm{mg} / \mathrm{L} \mathrm{Cr}(\mathrm{VI})$ was fed into the adsorption column at $\mathrm{pH}$ 2.0. A volume of $12.0 \mathrm{~L}$ was processed in the first cycle and a breakthrough time was observed at $60 \mathrm{~min}$ with $6.0 \mathrm{~L}$ feed. The column was left idle for $24 \mathrm{~h}$ in the off cycle. The break in the horizontal axis in Figure 2 corresponds to the dark period. At the end of this period, a relatively high $\mathrm{Cr}(\mathrm{III})$ concentration of $70 \mathrm{mg} / \mathrm{L}$ was observed in the eluent (red circle). The results indicate that for a $6.0 \mathrm{~L}$ feed of $100 \mathrm{mg} / \mathrm{L} \mathrm{Cr}(\mathrm{VI}), \mathrm{Cr}(\mathrm{III})$ is produced at ca. $5 \mathrm{mg} / \mathrm{L}$ after $70 \mathrm{~min}$ of operation. This indicates that reduction is simultaneous with adsorption, but it occurs at a slower rate. The 24-h dark period allows for reduction of additional adsorbed $\mathrm{Cr}(\mathrm{VI})$.

In the second run, the same feed concentration was used, the breakthrough time from the previous run was taken as a rough guideline, and the column was allowed a dark period after only $60 \mathrm{~min}$. The cycle was repeated by leaving the column idle for $24 \mathrm{~h}$ so as to permit reduction to proceed. After this dark period, Cr(III) spiked as expected, reaching a concentration of $130 \mathrm{mg} / \mathrm{L}$. In the second ON cycle, the column processed another $6.0 \mathrm{~L}$ of feed, giving $\mathrm{Cr}$ (III) concentrations below $5.0 \mathrm{mg} / \mathrm{L}$. This indicates that ca. $97 \%$ of column efficiency was recovered. The breakthrough curve for the two cycles is shown in Figure 3. The results from this run clearly point to the possibility of running the column without the need for regeneration if extended idle/dark periods are incorporated in operation cycles. 


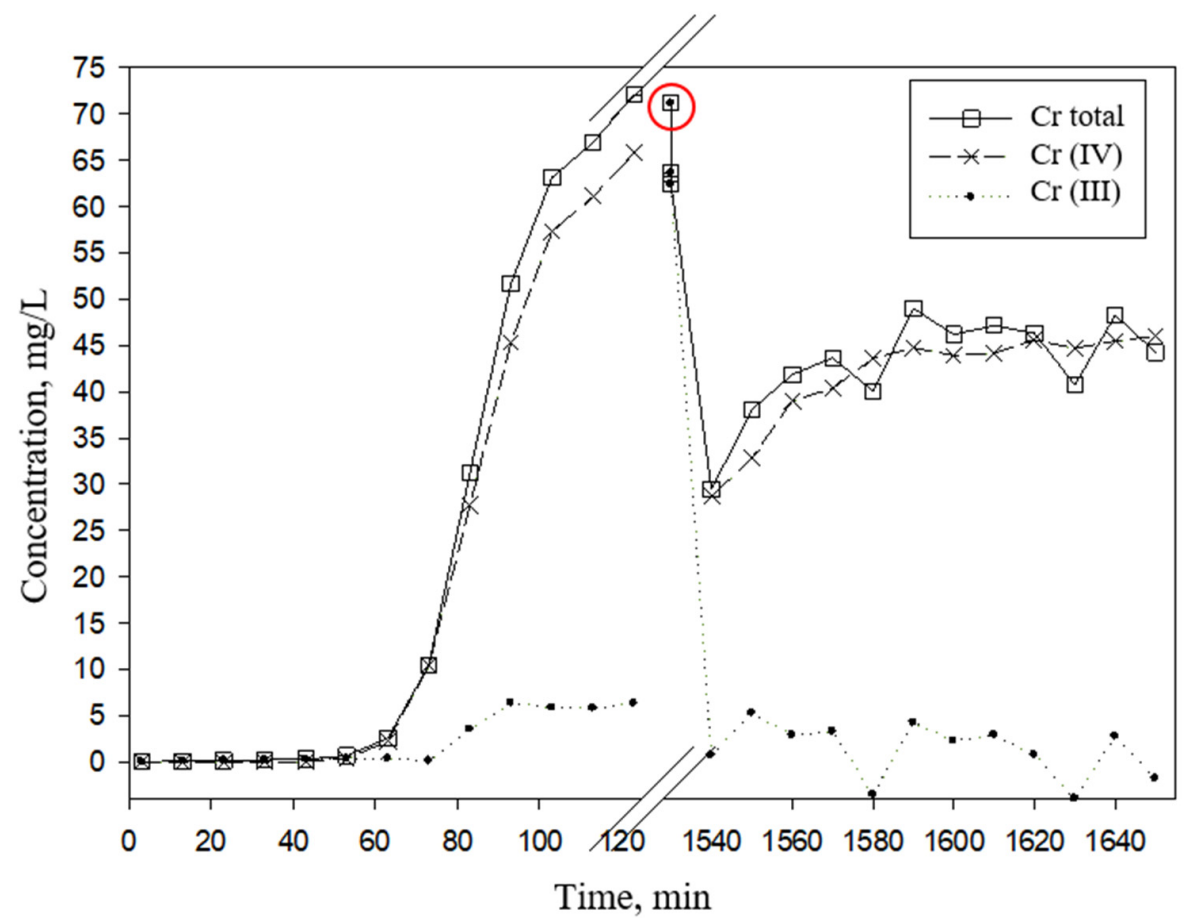

Figure 2. Chromium concentrations in the eluent. Initial $\mathrm{Cr}(\mathrm{VI})$ feed concentration $=100 \mathrm{mg} / \mathrm{L}$; flow rate $=200 \mathrm{~mL} / \mathrm{min}$; operation time $=2 \mathrm{~h}$, followed by dark interval of $24 \mathrm{~h}$, and then terminated by $2-\mathrm{h}$ operation; and $\mathrm{T}=25.0^{\circ} \mathrm{C}$.

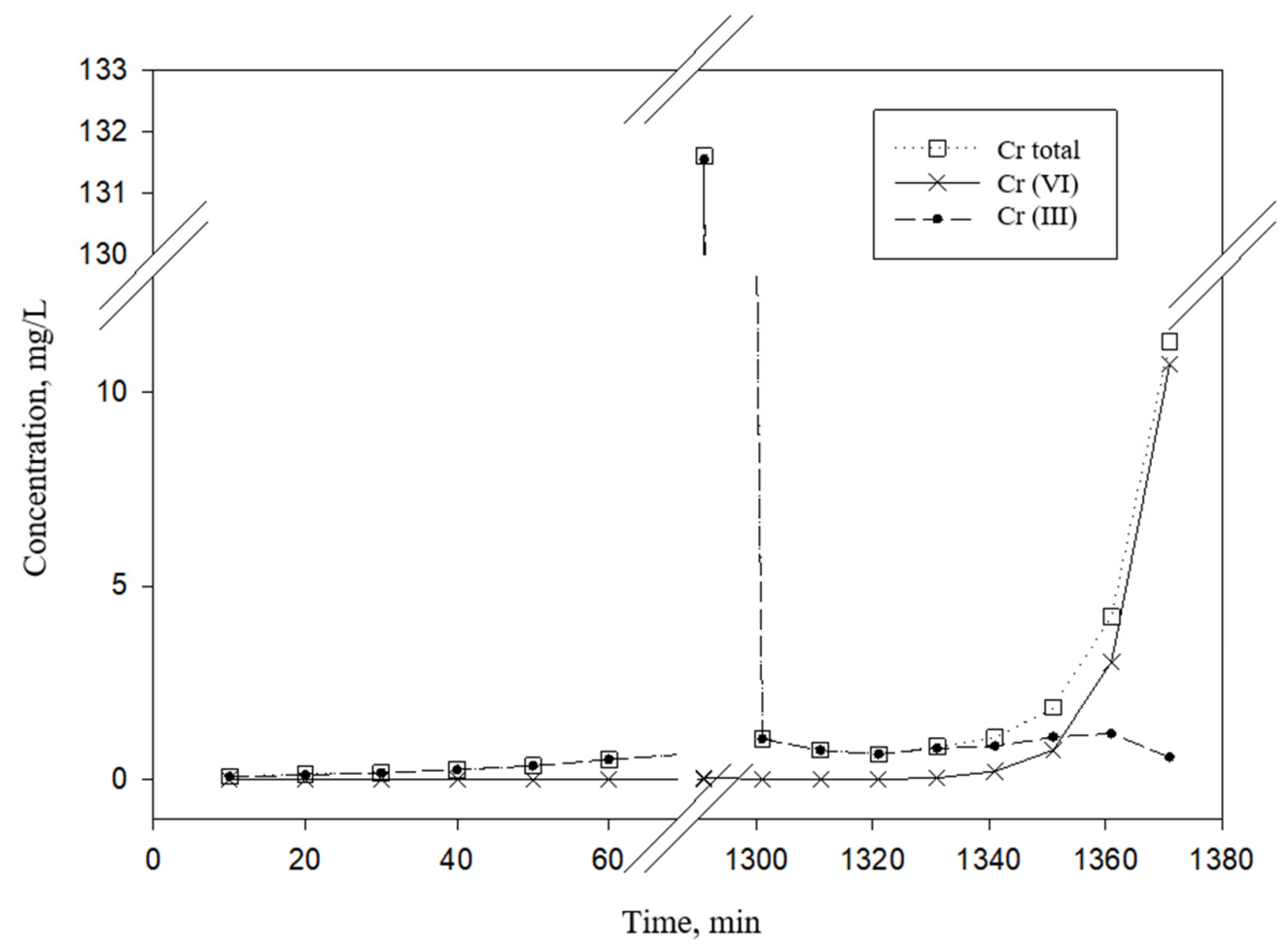

Figure 3. Chromium concentrations in eluent. Initial $\mathrm{Cr}(\mathrm{VI})$ feed concentration $=100 \mathrm{mg} / \mathrm{L}$; flow rate $=200 \mathrm{~mL} / \mathrm{min}$; operation time $=1 \mathrm{~h}$, followed by dark interval of $24 \mathrm{~h}$, and then terminated by $1-\mathrm{h}$ operation; and $\mathrm{T}=25.0^{\circ} \mathrm{C}$.

Now that a self-regenerating adsorption column has been demonstrated, the next step was to investigate its effectiveness in treating real wastewater containing $\mathrm{Cr}(\mathrm{VI})$. Other chemicals present in wastewater may interfere with adsorption or reduction, or may compete with $\mathrm{Cr}(\mathrm{VI})$ and adsorb on the 
wool surface. To investigate the possibility of antagonistic interactions with other metals, wastewater from a local electroplating company was analyzed for total $\mathrm{Cr}, \mathrm{Cr}(\mathrm{VI}), \mathrm{Cu}, \mathrm{Mn}, \mathrm{Ni}, \mathrm{Pb}$, and $\mathrm{Zn}$. As the concentrations of total $\mathrm{Cr}$ and $\mathrm{Cr}(\mathrm{VI})$ were high, the wastewater was diluted to obtain concentrations ca. $600 \mathrm{mg} / \mathrm{L}$ for $\mathrm{Cr}(\mathrm{VI})$, so that $1.0 \mathrm{~L}$ of feed can be processed in the column in accordance with the previous results.

Table 1 lists the heavy metals concentrations. The column processed $6.0 \mathrm{~L}$ of $100 \mathrm{mg} / \mathrm{L} \mathrm{Cr}(\mathrm{VI})$ in the previous run before the breakthrough concentration of $1.0 \mathrm{mg} / \mathrm{L}$ was exceeded, as shown in Figure 2 . The column was therefore expected to process only $1.0 \mathrm{~L}$ of $600 \mathrm{mg} / \mathrm{L} \mathrm{Cr}(\mathrm{VI})$. Hence, an additional interval of $55 \mathrm{~min}$, during which the flow was interrupted, was introduced to maintain a comparable load per unit time on the adsorbent. Figure 4 shows that with ca. 6-fold higher concentration of $\mathrm{Cr}(\mathrm{VI}), 5.0 \mathrm{~L}$ of feed was processed before the breakthrough concentration was reached. Moreover, the other metals present in the wastewater had no effect on adsorption. The concentrations of these metals remained at values around the original feed concentrations (Figure 5), with slight fluctuations resembling a sine wave when examined closely. This pattern is consistent with repeated cycles of adsorption-desorption.

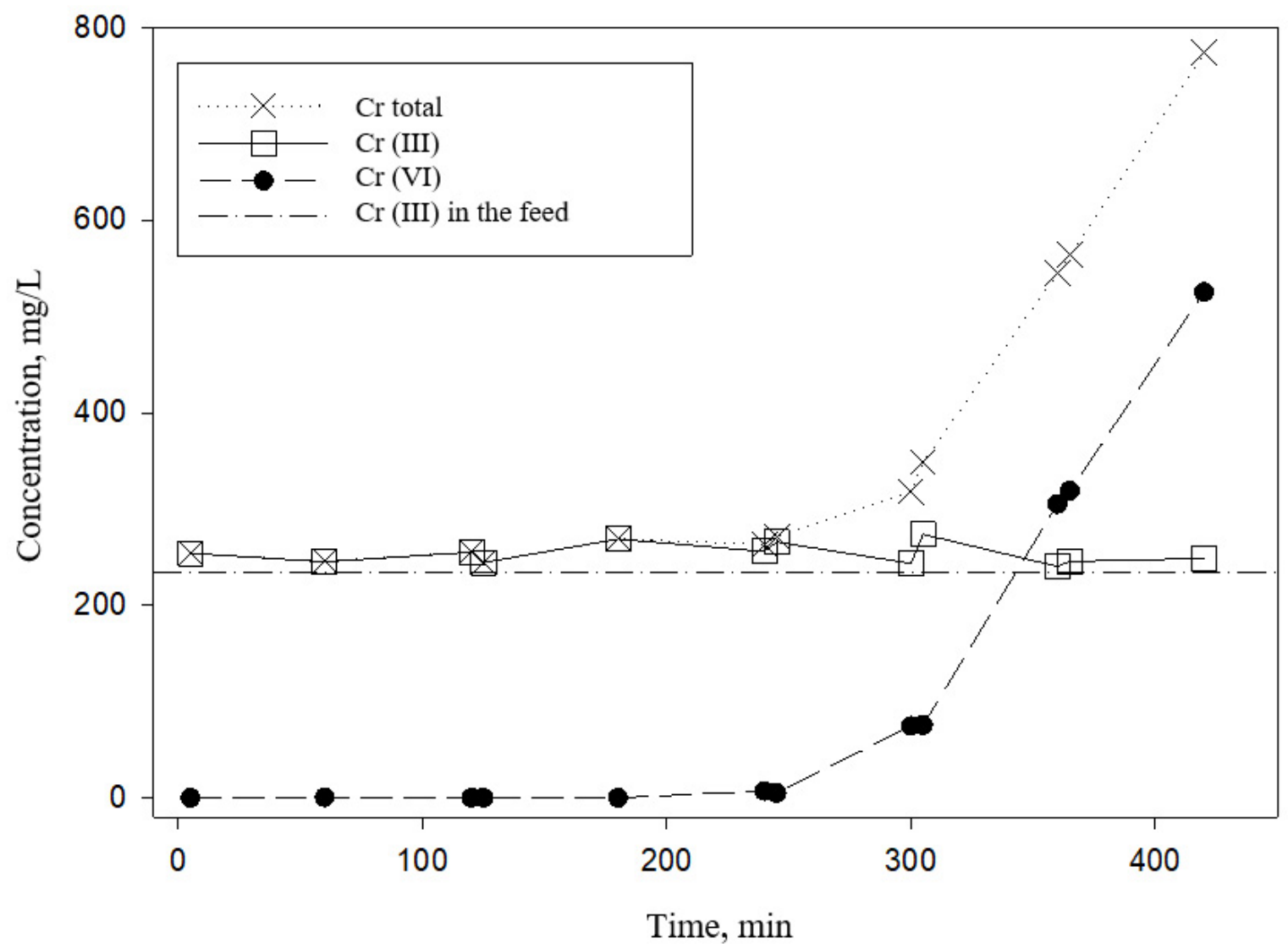

Figure 4. Chromium concentrations in the eluent. Initial $\mathrm{Cr}(\mathrm{VI})$ feed concentration (from electroplating wastewater $)=620 \mathrm{mg} / \mathrm{L}$, flow rate $=200 \mathrm{~mL} / \mathrm{min}$, operation time $=5 \mathrm{~min}$ followed by dark interval of $55 \mathrm{~min}$, and $\mathrm{T}=25.0^{\circ} \mathrm{C}$.

Reduction of $\mathrm{Cr}(\mathrm{VI})$ is due to cysteine in wool. Cysteine thiols can be oxidized to produce sulfur-containing acids, namely sulfenic $[\mathrm{R}-\mathrm{S}-\mathrm{O}-\mathrm{H}]$, sulfinic $[\mathrm{R}-\mathrm{S}=\mathrm{O}(\mathrm{OH})]$ and sulfonic $\left[\mathrm{S}(=\mathrm{O})_{2}(\mathrm{OH})\right][28]$, in addition to disulfides and persulfides [29]. In a previous study from this lab, FTIR analysis of wool used to adsorb $\mathrm{Cr}(\mathrm{VI})$ showed that $\mathrm{S}=\mathrm{O}$ bonds were affected, indicating that cysteine was involved in adsorption as an electron donor [22]. It is noteworthy that, in the presence of oxidants such as hydrogen peroxide, cysteine can be oxidized to sulfinic and sulfonic acids [30]. 


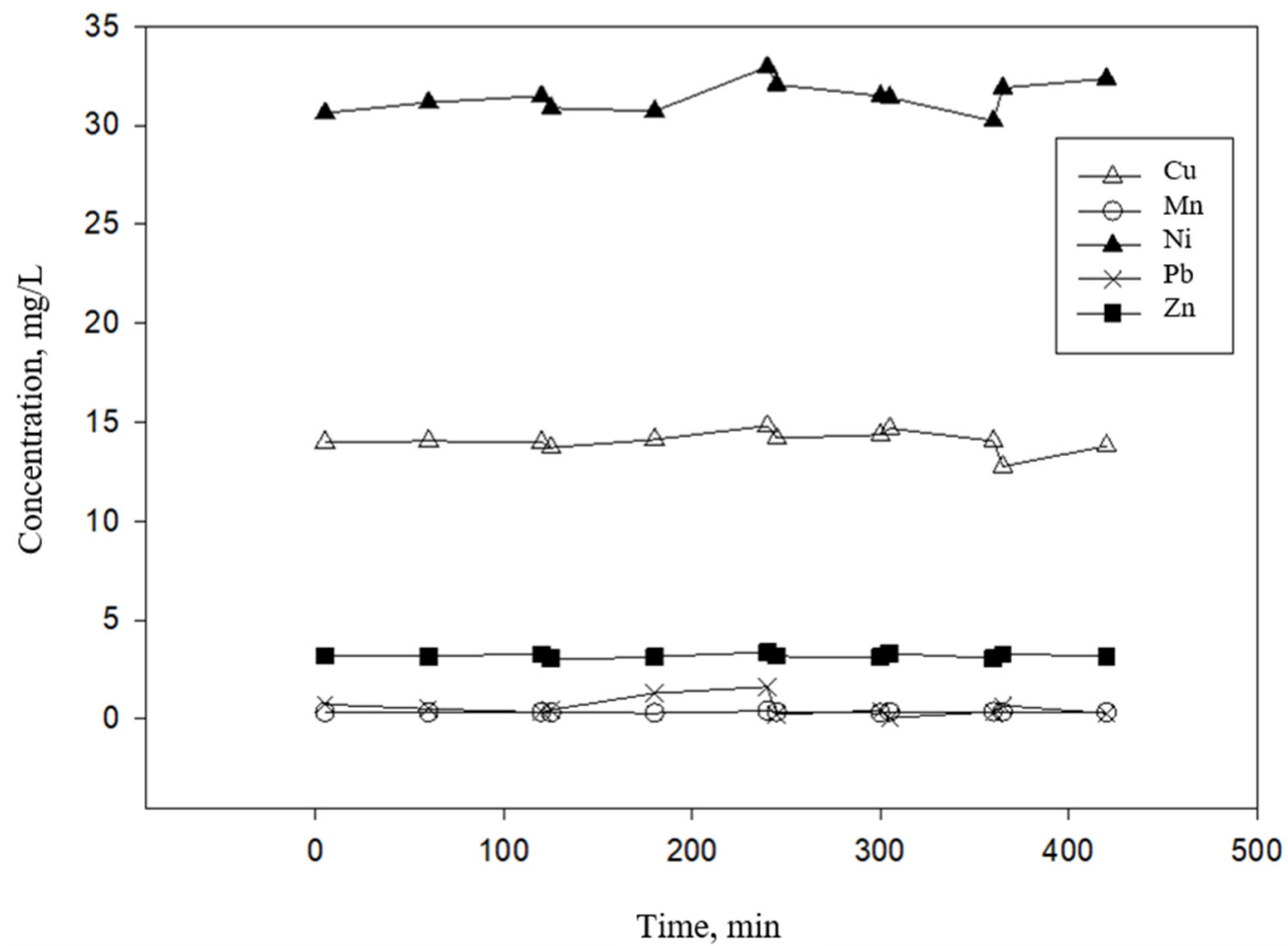

Figure 5. Heavy metal concentrations in the eluent. Initial feed is electroplating wastewater, flow rate $=200 \mathrm{~mL} / \mathrm{min}$, operation time $=5 \mathrm{~min}$ followed by dark interval of $55 \mathrm{~min}$, and $\mathrm{T}=25.0{ }^{\circ} \mathrm{C}$.

Extension to additional cycles was also tested. In Figure 6, each point represents $2.0 \mathrm{~L}$ of processed wastewater, with a total of $8.0 \mathrm{~L}$ in each cycle. The first break denotes the first $24-\mathrm{h}$ dark time, followed by a spike in $\mathrm{Cr}(\mathrm{III})$. After an additional $8.0 \mathrm{~L}$ of wastewater was processed, a second 24-h dark period was initiated, after which another spike in $\mathrm{Cr}(\mathrm{III})$ was observed, with the concentration of $\mathrm{Cr}(\mathrm{VI})$ remaining below $5.0 \mathrm{mg} / \mathrm{L}$ The slope observed in the first cycle is due to the effect of dilution, as experiments were carried out using an initially water filled column.

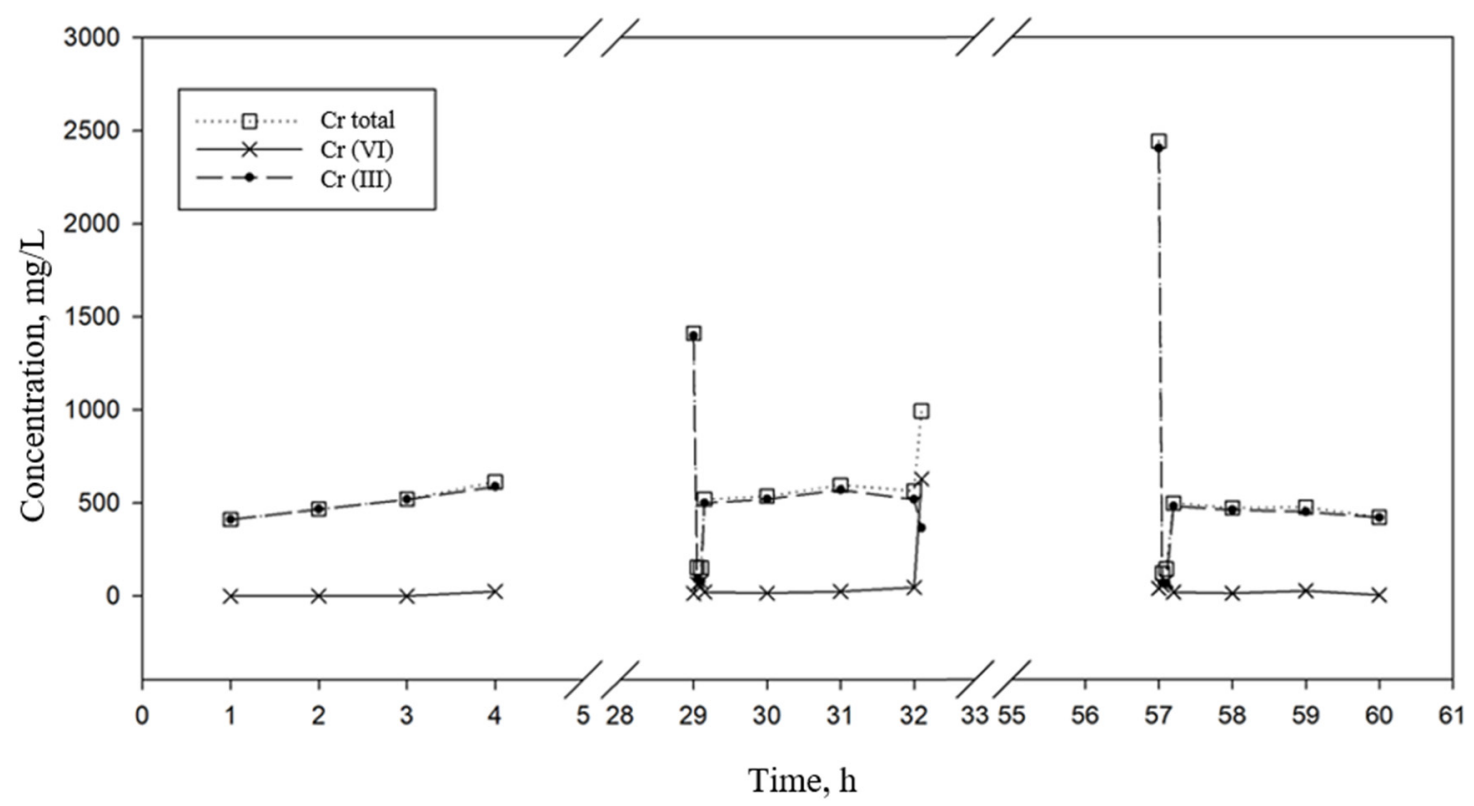

Figure 6. Chromium concentrations in the eluent for three consecutive cycles. Initial $\mathrm{Cr}(\mathrm{VI})$ feed concentration (from electroplating wastewater) $=620 \mathrm{mg} / \mathrm{L}$, flow rate $=200 \mathrm{~mL} / \mathrm{min}$, operation time $=5 \mathrm{~min}$ followed by a dark interval of $55 \mathrm{~min}$, and $\mathrm{T}=25.0{ }^{\circ} \mathrm{C}$. 
An increase in solution $\mathrm{pH}$ accompanies the reduction that takes place when wastewater is processed, particularly during the $24 \mathrm{~h}$ dark period. Adsorption is highly dependent on $\mathrm{pH}$, as results from batch studies indicate $[21,23]$. The optimum $\mathrm{pH}$ of 2.0 has led to ca. $99 \%$ removal of $\mathrm{Cr}(\mathrm{VI})$. Thus, an increase wastewater $\mathrm{pH}$ will lead to a decrease in adsorption efficiency. To ensure that $\mathrm{pH}$ does not exceed the optimum value, two possible treatments can be made. The first is to start with a $\mathrm{pH}$ lower than the optimum. The second is to process $\mathrm{HCl}$ at low $\mathrm{pH}(1.0)$ immediately before the dark cycle. The second procedure was used, albeit the data were somewhat distorted as some $\mathrm{Cr}(\mathrm{VI})$ washes out, giving peaks at the beginning of Cycles 2 and 3. Whenever such peaks are observed, the eluent should be diverted to the feed for retreatment. The observed increase in $\mathrm{pH}$ is roughly one unit (from 1 to 2 ), with the higher $\mathrm{pH}$ being within the optimum range for adsorption, as shown in Figure 7. Wool is stable over a wide range of $\mathrm{pH}$ [31] and its high surface area facilitates absorption. The potential/pH (Pourbaix) diagrams for chromium in the $\mathrm{pH} 1-2$ range show that at a redox potential of $1.1 \mathrm{~V} \mathrm{Cr}(\mathrm{VI})$ is dominant, and below $-1.0 \mathrm{~V}$ metallic $\mathrm{Cr}$ is dominant. $\mathrm{Cr}$ (III) exists between -1.0 and $-0.1 \mathrm{~V}$ and $\mathrm{Cr}$ (II) between -0.1 and $1.1 \mathrm{~V}$. Thus, $\mathrm{Cr}(\mathrm{III})$ is generally more stable at low $\mathrm{pH}$ and oxidizes to $\mathrm{Cr}(\mathrm{VI})$ at high $\mathrm{pH}$ [32]. Reduction of $\mathrm{Cr}(\mathrm{VI})$ to $\mathrm{Cr}(\mathrm{III})$ occurs at low $\mathrm{pH}$, at which protonated active sites generate electrostatic attraction for $\mathrm{Cr}(\mathrm{VI})$. This is explained by $\mathrm{H}^{+}$causing reduction of $\mathrm{Cr}(\mathrm{VI})$ into $\mathrm{Cr}(\mathrm{III})$ [33] as shown below:

$$
\begin{aligned}
\mathrm{Cr}_{2} \mathrm{O}_{7}^{-2}+14 \mathrm{H}^{+}+6 \mathrm{e}^{-} & \leftrightarrow 2 \mathrm{Cr}^{+3}+7 \mathrm{H}_{2} \mathrm{O} \\
\mathrm{CrO}_{4}^{-2}+8 \mathrm{H}^{+}+3 \mathrm{e}^{-} & \leftrightarrow \mathrm{Cr}^{+3}+4 \mathrm{H}_{2} \mathrm{O} \\
\mathrm{HCrO}_{4}^{-}+7 \mathrm{H}^{+}+3 \mathrm{e}^{-} & \leftrightarrow \mathrm{Cr}^{+3}+4 \mathrm{H}_{2} \mathrm{O} \\
\mathrm{H}_{2} \mathrm{CrO}_{4}+6 \mathrm{H}^{+}+3 \mathrm{e}^{-} & \leftrightarrow \mathrm{Cr}^{+3}+4 \mathrm{H}_{2} \mathrm{O}
\end{aligned}
$$

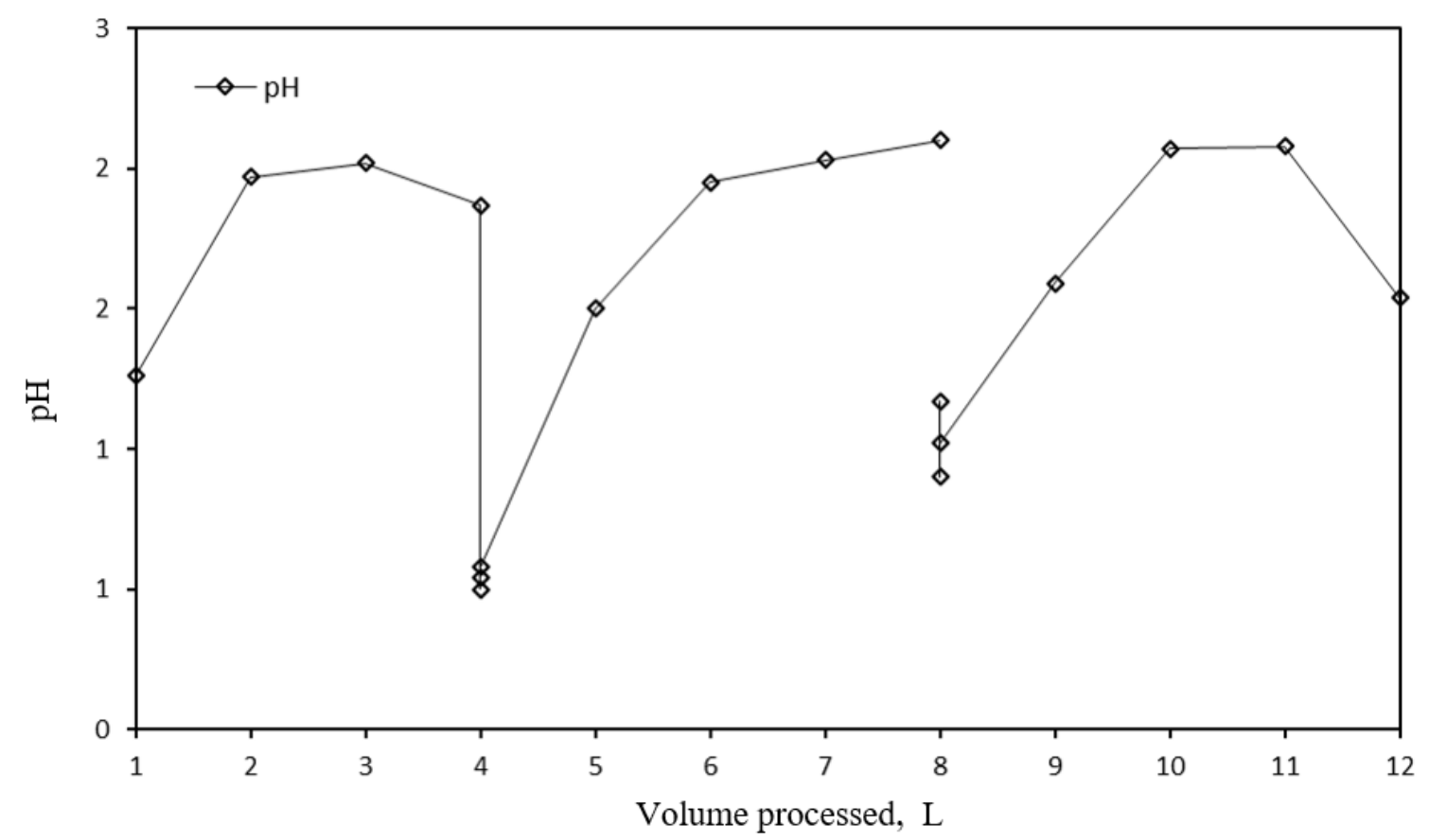

Figure 7. Variation of $\mathrm{pH}$ in eluents for three consecutive operation cycles. Initial $\mathrm{Cr}(\mathrm{VI})$ feed concentration (from electroplating wastewater) $=620 \mathrm{mg} / \mathrm{L}$, flow rate $=200 \mathrm{~mL} / \mathrm{min}$, operation time $5 \mathrm{~min}$ followed by dark interval of $55 \mathrm{~min}$, and $\mathrm{T}=25.0^{\circ} \mathrm{C}$.

The mechanism proposed earlier [22] for adsorption and reduction of chromium on wool can be amended to accommodate the role of $\mathrm{H}^{+}$in the process so that the mechanism can now be written as:

$$
\mathrm{Cr}^{+6}+\text { wool }+\mathrm{H}^{+} \rightarrow\left(\mathrm{Cr}^{+6}\right) \cdots(\text { wool } \cdot \mathrm{H})^{+} \rightarrow\left(\mathrm{Cr}^{+3}\right) \cdots(\text { wool }) \rightarrow \mathrm{Cr}^{+3}+\text { wool }
$$




\section{Conclusions}

This work demonstrates the efficacy of a semi-continuous adsorption column for adsorption and reduction of $\mathrm{Cr}(\mathrm{VI})$ to $\mathrm{Cr}(\mathrm{III})$. This column can operate with reduced need for regeneration. A dark period of $24 \mathrm{~h}$ was found to be sufficient for regeneration of the packing for subsequent operation cycles as it allows for reduction of $\mathrm{Cr}(\mathrm{VI})$ to $\mathrm{Cr}(\mathrm{III})$. The presence of other heavy metals, in concentrations found in a typical electrochemical polishing facility waste, had no influence on the efficiency of the adsorption column. As $\mathrm{pH}$ highly affects adsorption efficiency, eluent $\mathrm{pH}$ was monitored. Measurements show that the operating $\mathrm{pH}$ does not increase above 2.0 for the chosen operating cycle periods. That $\mathrm{pH}$ was found to be optimal in previous batch adsorption experiments.

Author Contributions: M.B. performed most of the experiments. This research was led by T.H.I., M.I.K. and F.H.J. who were also instrumental in the initiation, conceptualization and planning of this work. All authors have read and agreed to the published version of the manuscript.

Funding: This research received no external funding.

Acknowledgments: The authors thank the American University of Sharjah for supporting this work through research grant FRG-17-R-17 and through the partial support by the Open Access Program from the American University of Sharjah. This paper represents the opinions of the author(s) and does not mean to represent the position or opinions of the American University of Sharjah.

Conflicts of Interest: The authors declare no conflict of interest.

\section{References}

1. Tchounwou, P.B.; Yedjou, C.G.; Patlolla, A.K.; Sutton, D.J. Heavy metal toxicity and the environment. In Molecular, Clinical and Environmental Toxicology; Springer: Basel, Switzerland, 2012; Volume 101, pp. 133-164. [CrossRef]

2. Costa, M.; Klein, C.B. Toxicity and carcinogencity of chromium compounds in humans. Crit. Rev. Toxicol. 2006, 36, 155-163. [CrossRef] [PubMed]

3. Barnhart, J. Occurrences, uses, and properties of chromium. Regul. Toxicol. Pharmacol. 1997, 1, S3-S7. [CrossRef]

4. Lunk, H.-J. Discovery, Properties and Applications of Chromium and its Compounds. Chem. Texts 2015, 1, 1-7. [CrossRef]

5. Mohan, D.; Pittman, C.U.P., Jr. Activated carbons and low cost adsorbents for remediation of tri- and hexavalent chromium from water. J. Hazard. Mater. 2006, 177, 762-811. [CrossRef] [PubMed]

6. Kendig, M.; Jeanjaquet, S.; Addison, R.; Waldrop, J. Role of hexavalent chromium in the inhibition of corrosion of aluminum alloys. Surf. Coat. 2001, 140, 58-66. [CrossRef]

7. Pavithra, K.G.; Jaikumar, V.; Kumar, M.M.; Sundarrajan, P. A review on cleaner strategies for chromium industrial wastewater: Present research and future perspective. J. Clean. Prod. 2019, 228, 580-593. [CrossRef]

8. Kimbrough, D.E.; Cohen, Y.; Winer, A.M.; Creelman, L.; Mabuni, C. A critical assessment of chromium in the environment. Crit. Rev. Environ. Sci. Technol. 1999, 29, 1-46. [CrossRef]

9. Bakshi, A.; Panigrahi, A. A comprehensive review on chromium induced alterations in fresh water fishes. Toxicol. Rep. 2018, 5, 440-447. [CrossRef]

10. Occupational Safety and Health Administration. Occupational Exposure to Hexavalent Chromium. Final Rule; Federal Register; Occupational Safety and Health Administration: Washington, DC, USA, 2006; pp. 10099-10385.

11. Miningwatch Canada. Chromium, chromite min. ferrochrome Prod. In Potential Toxic Effects of Chromium, Chromite Mining and Ferrochrome Production: A Literature Review; MiningWatch Canada: Ottawa, ON, Canada, 2012; pp. 1-42.

12. Vaiopoulou, E.; Gikas, P. Effects of chromium on activated sludge and on the performance of wastewater treatment plants: A review. Water Res. 2012, 46, 549-570. [CrossRef]

13. Cavaco, S.A.; Fernandes, S.; Quina, M.J.; Ferreira, L.M.G. Ferreira, Removal of chromium from electroplating industry by ion exchange resins. J. Hazard. Mater. 2007, 144, 634-648. [CrossRef]

14. Hafiane, A.; Lemordant, D.; Dhahbi, M. Removal of hexavalent chromium by nanofiltration. Desalination 2000, 130, 305-312. [CrossRef] 
15. Benito, Y.; Ruiz, M. Reverse osmosis applied to metal finishing wastewater. Desalination 2002, 142, $229-234$. [CrossRef]

16. Mant, C.; Costa, S.; Williams, J.B.; Tambourgi, E. Phytoremediation of chromium by model constructed wetland. Bioresour. Technol. 2006, 15, 1767-1772. [CrossRef] [PubMed]

17. Deeb, R.; Kavanaugh, M.; Hawley, E.; Jacobs, J. Treatment technologies for chromium(VI). In Chromium(VI) Handbook; CRC Press: Boca Raton, FLA, USA, 2004.

18. Henryk, K.; Jaroslaw, C.; Witold, Z. Peat and coconut fiber as biofilters for chromium adsorption from contaminated wastewaters. Environ. Sci. Pollut. Res. Int. 2016, 23, 527-534. [CrossRef] [PubMed]

19. Saha, S.; Zubair, M.; Khosa, M.A.; Song, S.; Ullah, A. Keratin and chitosan biosorbents for wastewater treatment: A review. J. Polym. Environ. 2019, 27, 1389-1403. [CrossRef]

20. Dakiky, M.; Khamis, M.I.; Manassra, A.; Mer'Eb, M. Selective adsorption of chromium(VI) in industrial wastewater using low-cost abundantly available adsorbents. Adv. Environ. Res. 2002, 6, 533-540. [CrossRef]

21. Ray, P.; Sabri, M.A.; Ibrahim, T.H.; Khamis, M.I.; Jumean, F.H. Design and optimization of a batch sequential contactor for the removal of chromium(VI) from industrial wastewater using sheep wool as a low-cost adsorbent. Deswater 2018, 113, 109-113. [CrossRef]

22. Jumean, F.H.; Khamis, M.I.; Sara, Z.A.; AbouRich, M.S. Concurrent removal and reduction of Cr(VI) by wool: Short and long term equilibration studies. Am. J. Anal. Chem. 2015, 6, 47-57. [CrossRef]

23. Balkaya, N.; Bektas, N. Chromium(VI) sorption from dilute aqueous solutions using wool. Deswater 2012, 3, 43-49. [CrossRef]

24. Aksu, Z.; Akpinar, D. Competitive biosorption of phenol and chromium(VI) from binary mixtures onto dried anaerobic activated sludge. Biochem. Eng. J. 2001, 7, 183-193. [CrossRef]

25. Huang, C.P.; Bowers, A.R. Activated carbon process for treatment of wastewaters containing hexavalent chromium. In EPA-600/279-130; US Environmental Protection Agency: Washington, DC, USA, 1979.

26. Miretzky, P.; Cirelli, A.F. Cr(VI) and Cr(III) removal from aqueous solution by raw and modified lignocellulosic materials: A review. J. Hazard. Mater. 2010, 180, 1-19. [CrossRef] [PubMed]

27. Hongmei, W.; Xiao, Y.; Guo, Y.; Miao, S.; Chen, Q.; Chen, Z. Functionalization of SBA-15 mesoporous materials with 2-acetylthiophene for adsorption of Cr(III) ions. Microporous Mesoporous Mater. 2020, 292, 109754.

28. Yarnell, A. Cysteine oxidation. Chem. Eng. News 2009, 87, 38-40. [CrossRef]

29. Alcock, L.J.; Perkins, M.V.; Chalker, J.M. Chemical methods for mapping cysteine oxidation. Chem. Soc. Rev. 2018, 47, 231-268. [CrossRef]

30. Poole, L.B. The basics of thiols and cysteines in redox biology and chemistry. Free Radic. Biol. Med. 2015, 80, 148-159. [CrossRef] [PubMed]

31. Kar, P.; Misra, M. Use of keratin fiber for separation of heavy metals from water. J. Chem. Technol. Biotechnol. 2004, 79, 1313-1319. [CrossRef]

32. Pradhan, D.; Sukla, L.B.; Sawyer, M.; Rahman, P.K. Recent bioreduction of hexavalent chromium in wastewater treatment: A review. J. Ind. Eng. Chem. 2017, 55, 1-20. [CrossRef]

33. Silva, B.; Figueiredo, H.; Quintelas, C.; Neves, I.C.; Tavares, T. Improved biosorption for Cr(VI) reduction and removal by Arthrobacter viscosus using zeolite. Int. Biodeterior. Biodegrad. 2012, 74, 116-123. [CrossRef]

(C) 2020 by the authors. Licensee MDPI, Basel, Switzerland. This article is an open access article distributed under the terms and conditions of the Creative Commons Attribution (CC BY) license (http://creativecommons.org/licenses/by/4.0/). 